\title{
Negative surgical exploration in patients with Cushing's disease: benefit of two-thirds gland resection on remission rate and a review of the literature
}

\author{
Steven B. Carr, MD, ${ }^{1}$ Bette K. Kleinschmidt-DeMasters, MD, ${ }^{1,2}$ Janice M. Kerr, MD, ${ }^{3}$ \\ Katja Kiseljak-Vassiliades, DO, ${ }^{3}$ Margaret E. Wierman, MD, ${ }^{3}$ and Kevin O. Lillehei, MD1 \\ ${ }^{1}$ Department of Neurosurgery, ${ }^{2}$ Department of Pathology, and ${ }^{3}$ Division of Endocrinology, Department of Medicine, University of \\ Colorado Denver School of Medicine, Denver, Colorado
}

\begin{abstract}
OBJECTIVE The authors report their single-institution experience with the pathological findings, rates of remission, and complications in patients with presumed Cushing's disease (CD) who underwent a two-thirds pituitary gland resection when no adenoma was identified at the time of transsphenoidal surgery (TSS). The authors also review the literature on patients with $C D$, negative surgical exploration, and histological findings.

METHODS This study is a retrospective analysis of cases found in neurosurgery and pathology department databases between 1989 and 2011. In all cases, patients had been operated on by the same neurosurgeon (K.O.L.). Twenty-two (13.6\%) of 161 patients who underwent TSS for CD had no adenoma identified intraoperatively after systematic exploration of the entire gland; these patients all underwent a two-thirds pituitary gland resection. A chart review was performed to assess treatment data points as well as clinical and biochemical remission status.
\end{abstract}

RESULTS Of the 22 patients who underwent two-thirds gland resection, $6(27.3 \%)$ ultimately had lesions found on final pathology. All 6 patients were found to have a distinct adrenocorticotropic hormone (ACTH) cell adenoma. Sixteen (72.7\%) of the patients had no tumor identified, with 3 of these patients suspected of having ACTH cell hyperplasia. The follow-up duration for the entire group was between 14 and 315 months (mean 98.9 months, median 77 months). Remission rates were $100 \%$ (6/6 patients) for the ACTH cell adenoma group and $75 \%$ (12/16) for the group without adenoma. Overall, $18(81.8 \%)$ of the 22 patients had no evidence of hypercortisolism at last follow-up, and 4 patients (18\%) had persistent hypercortisolism, defined as a postoperative cortisol level $>5 \mu \mathrm{g} / \mathrm{dl}$. Of these 4 patients, 1 was suspected of harboring a cavernous sinus adenoma, 2 were found to have lung tumors secreting $\mathrm{ACTH}$, and 1 remained with an undiagnosed etiology. Rates of postoperative complications were low.

CONCLUSIONS The diagnosis and treatment of CD can be challenging for neurosurgeons, endocrinologists, and pathologists alike. Failure to find a discrete adenoma at the time of surgery occurs in at least $10 \%-15 \%$ of cases, even in experienced centers. The current literature provides little guidance regarding rational intraoperative approaches in such cases. The authors' experience with 161 patients with CD, when no intraoperative tumor was localized, demonstrates the utility of a two-thirds pituitary gland resection with a novel and effective surgical strategy, as suggested by a high initial remission rate and a low operative morbidity.

https://thejns.org/doi/abs/10.3171/2017.5.JNS162901

KEY WORDS Cushing's disease; resection; outcome; adenoma; transsphenoidal; pituitary surgery

$\mathrm{H}$ YPERCORTISOLISM from an adrenocorticotropic hormone (ACTH)-secreting pituitary tumor, also known as Cushing's disease (CD), is an endocrinopathy with significant associated morbidity and mortality. Patients exposed to chronic hypercortisolism are prone to multiple metabolic, cardiovascular, and infectious risks, including hypertension, diabetes mellitus, opportunistic infections, hyperlipidemia, and hypercoagulability. Untreated, CD is associated with upwards of a 5.5-fold increased mortality risk. ${ }^{12}$

The most common cause of CD is an ACTH-secreting pituitary microadenoma (70\%). In these patients, trans-

ABBREVIATIONS $\mathrm{ACTH}=$ adrenocorticotropic hormone; $\mathrm{CD}=$ Cushing's disease; $\mathrm{CRH}=$ corticotropin-releasing hormone; $\mathrm{DST}=$ dexamethasone suppression test; $\mathrm{EOR}$ = extent of resection; HPA = hypothalamic-pituitary-adrenocortical; IPSS = inferior petrosal sinus sampling; TSS = transsphenoidal surgery.

SUBMITTED November 28, 2016. ACCEPTED May 15, 2017.

INCLUDE WHEN CITING Published online December 8, 2017; DOI: 10.3171/2017.5.JNS162901. 
sphenoidal pituitary exploration and adenomectomy is highly effective and the first-line therapy. ${ }^{33}$ Remission rates at experienced pituitary centers range between $70 \%$ and $90 \%$. $1,6,9,10,11,18,19,24,27,29-31$

While many diagnostic tests aid in the localization of ACTH-dependent disease to the pituitary gland (such as ACTH level, pituitary MRI, and inferior petrosal sinus sampling [IPSS]), all of these studies have known weaknesses, and presence of a tumor is not always confirmed. ${ }^{2}$ Ultimately, it falls to the discretion of the surgeon on how to manage presumed $\mathrm{CD}$ cases when no obvious adenoma is discovered at the time of surgery. This paper describes our experience with using a systematic two-thirds gland resection strategy in this situation.

\section{Methods}

\section{Patient Selection}

A retrospective chart review was performed of a single surgeon's (K.O.L.) experience with the treatment of CD over a 22-year period (January 1989 to January 2011). During this time, approximately 1040 transsphenoidal surgeries (TSSs) were performed, 161 of which were in patients with CD. In 22 patients, no definitive adenoma was discovered at surgery and thus a systematic two-thirds gland resection was performed using a consistent technique. $\mathrm{Pa}-$ tient age ranged from 16 to 71 years old (mean 44 years). Forty-five percent of patients were male and $55 \%$ were female (Table 1). Three of the 22 patients had an abnormal pituitary MRI scan consistent with tumor and did not undergo IPSS. A total of 19 patients $(19 / 22,86.4 \%)$ had normal MRI and underwent IPSS. In the 6 patients found to have a definite adenoma, 4 had undergone IPSS sampling. In 3 of these patients, IPSS localized correctly to the side of the adenoma, whereas in 1 patient, it was incorrect. Details regarding outcome were extracted from the medical record and telephone follow-up, including remission rates and complications. All intraoperative consultations by the pathologist included both touch/smear preparations and frozen sections.

\section{Diagnosis}

All patients had been referred to the Department of Neurosurgery at the University of Colorado School of Medicine for consideration of transsphenoidal resection of a presumed ACTH-secreting pituitary adenoma; all had undergone an extensive workup either from a referring outside endocrinologist or from the University of Colorado Pituitary Endocrinology Service. The standard workup for $\mathrm{CD}$, in the setting of patients with clinical signs and symptoms of Cushing's syndrome, included: 1) excluding potential exogenous sources of glucocorticoid use and "pseudo-Cushing's disease;" 2) establishing hypercortisolism from among multiple different but concordantly positive screening tests, including 24-hour urinaryfree cortisol, a low-dose dexamethasone suppression test (DST), and midnight salivary cortisol tests; 3 ) establishing ACTH dependency with a baseline plasma ACTH level (generally > $20 \mathrm{ng} / \mathrm{dl}$ ); and 4) determining a pituitary source of an ACTH tumor with contrast-enhanced pituitary MRI. In cases in which a distinct pituitary adenoma

TABLE 1. Patient summary

\begin{tabular}{|c|c|c|c|c|c|}
\hline Case No. & Age (yrs), Sex & IPSS & DST & Final Pathology & Remission (mos) \\
\hline 1 & $67, \mathrm{M}$ & Positive (lt > rt) & Positive & No adenoma & Yes (67) \\
\hline 2 & $52, \mathrm{M}$ & Positive (lt > rt) & Positive & Adenoma (It) & Yes (68) \\
\hline 3 & $21, \mathrm{~F}$ & Positive (rt > It) & Positive & No adenoma & Yes (73) \\
\hline 4 & $56, \mathrm{M}$ & Positive (lt > rt) & Positive & No adenoma & Yes (73) \\
\hline 5 & $20, M$ & Positive (rt > It) & None & No adenoma & Yes (92) \\
\hline 6 & $48, M$ & Positive (rt > It) & Positive & No adenoma & Yes (24) \\
\hline 7 & $35, F$ & Positive (rt > It) & Positive & No adenoma (hyperplasia) & Yes (95) \\
\hline 8 & $16, F$ & Positive ( $r t=1 t)$ & Negative & No adenoma & No (76) \\
\hline 9 & $43, M$ & Positive (rt > It) & None & No adenoma (hyperplasia) & Yes (102) \\
\hline 10 & $43, \mathrm{~F}$ & Positive (rt > It) & Positive & No adenoma & No (32) \\
\hline 11 & $71, \mathrm{~F}$ & Positive (rt > It) & Positive & Adenoma (rt) & Yes (142) \\
\hline 12 & $36, M$ & Positive (lt > rt) & Positive & Adenoma (It) & Yes (116) \\
\hline 13 & $51, \mathrm{~F}$ & None (adenoma on MRI) & Positive & No adenoma & Yes (31) \\
\hline 14 & $68, F$ & Positive (lt > rt) & Positive & No adenoma & Yes (74) \\
\hline 15 & $44, \mathrm{~F}$ & Positive (lt > rt) & Positive & Adenoma (inferior) & Yes (178) \\
\hline 16 & $40, F$ & Positive (rt > It) & Positive & No adenoma (hyperplasia) & No (233) \\
\hline 17 & $43, \mathrm{M}$ & Positive (rt > It) & Positive & No adenoma & No (315) \\
\hline 18 & $43, \mathrm{~F}$ & None (adenoma on MRI) & Positive & Adenoma (It) & Yes (131) \\
\hline 19 & $34, \mathrm{M}$ & None (adenoma on MRI) & Positive & Adenoma (rt) & Yes (49) \\
\hline 20 & $39, F$ & Positive (lt > rt) & None & No adenoma & Yes (14) \\
\hline 21 & $55, \mathrm{M}$ & Positive (rt > It) & Positive & No adenoma & Yes (78) \\
\hline 22 & $45, \mathrm{~F}$ & Positive (lt > rt) & Positive & No adenoma & Yes (113) \\
\hline
\end{tabular}


was not identified, patients subsequently underwent IPSS. By definition, a central-to-peripheral ACTH gradient of more than 2 under basal conditions, or more than 3 with corticotropin-releasing hormone (CRH) stimulation, confirmed a pituitary source ${ }^{13}$ (e.g., CD). Strong evidence of a pituitary source for hypercortisolism was found in all patients (Table 1).

\section{Resection}

The operative strategy used was a stepwise pituitary gland exploration followed by a two-thirds gland resection when no adenoma was found. All surgeries were performed by the senior author (K.O.L.) using a transnasal transsphenoidal approach under microscopic magnification. After a wide opening of the sellar floor and exposure of the pituitary gland through a careful but extensive dural opening, the periphery of the gland was thoroughly explored. This included dissection between the lateral gland and the medial cavernous sinuses bilaterally, as well as over the superior and inferior surface of the gland. If no adenoma was found, exploration was carried into the gland itself. The first pituitary cut was made vertically on the lateral side of the gland most suspected of harboring an adenoma, as indicated by preoperative MRI, or more commonly, IPSS lateralization (Fig. 1). This side was explored and any suspicious tissue was sent for frozen sectioning. If no adenoma was confirmed by frozen section, a second vertical cut was made on the opposite side of the gland, and this side was explored. Any suspicious tissue was again resected and sent for frozen section. If no adenoma was confirmed on the frozen sections from either of the two lateral cuts, a third cut was performed horizontally across the midsection of the gland. If no discrete adenoma was found following this third cut, the incisions were carried through the full thickness of the anterior gland with resection of the bilateral and inferior sections, resulting in a two-thirds gland resection. No filter trap was used on surgical suction. All tissue was carefully labeled as

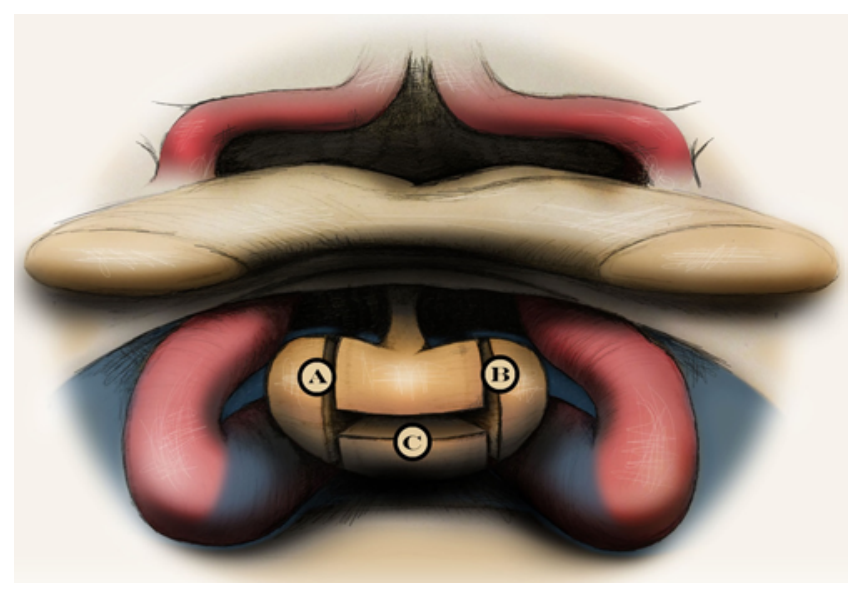

FIG. 1. Anterior view of the pituitary gland and surgical technique. Following peripheral gland exploration the first (A) and second (B) surgical incisions with associated lateral resection margins are made. The third surgical incision with associated inferior resection margin is then made (C). Copyright Zach Folzenlogen. Published with permission. separate specimens and sent to pathology for permanent analysis.

\section{Pathology}

Extensive sectioning of the tissue blocks was performed and sections were submitted for hematoxylin, reticulin stain, and immunostaining for $\mathrm{ACTH}$, with many additional sections submitted for immunostains of all anterior pituitary hormones (alpha subunit, growth hormone, prolactin, follicle stimulating hormone, luteinizing hormone, and thyroid-stimulating hormone). This resulted in approximately 30 glass slides per case to ensure that even minute adenomas were discerned, if present. In all cases in which no adenoma was identified, a careful search for Crooke's cells - a morphological proof of hypercortisolism (either endogenous or exogenous)-was also undertaken. In cases originally signed out by 1 of the authors (B.K.D.) this procedure was completed at the time of original diagnosis and included in the original report. In the 3 cases signed out by other neuropathologists at our institution, reexamination of the slides for the purposes of this study was undertaken.

\section{Results \\ Histopathological Results}

During surgery, 22 patients did not have an adenoma that could be diagnosed by the pathologists at the time of intraoperative consultation. The majority of cases had been seen by the senior neuropathologist at our institution (B.K.D.).

At the time of permanent section examination after surgery, 6 patients were ultimately diagnosed with adenoma (27.3\%; Fig. 2). Three patients had a definite minute adenoma in tissues not submitted for intraoperative consultation. One had a probable adenoma detectable only on the intraoperative touch preparation and lost on permanent section. One patient had a highly fibrotic adenoma that resulted in discordance between the few monotonous cells being shed at the time of touch preparation and the frozen section appearance, which led to hesitancy for definitive intraoperative diagnosis. The final patient had increased corticotroph cells at the junction between the anterior and posterior gland, which even on permanent section resulted in debate between physiological basophil invasion and true adenoma, although the latter was favored. Three patients $(13.6 \%)$ had suspected hyperplasia. One patient had the acinar expansion and increased hormone immunoreactivity necessary for suspicion of true hyperplasia and 2 patients had an apparent increase in ACTH immunoreactivity throughout the gland but without acinar expansion on the reticulin stain, thus resulting in uncertainty regarding true hyperplasia. The remaining 13 patients (59.1\%) had no confirmation of adenoma or suspected ACTH cell hyperplasia. The variability of these pathological findings underscores the difficulty with diagnosing microscopic adenomas and the possibility that a minute adenoma was lost at the time of intraoperative suctioning, leaving only questionable tissue for permanent sections.

Of the 13 instances in which no adenoma was identified histologically, 9 had been examined at the time of original diagnosis by 1 of the authors (B.K.D.). Eight of the 9 


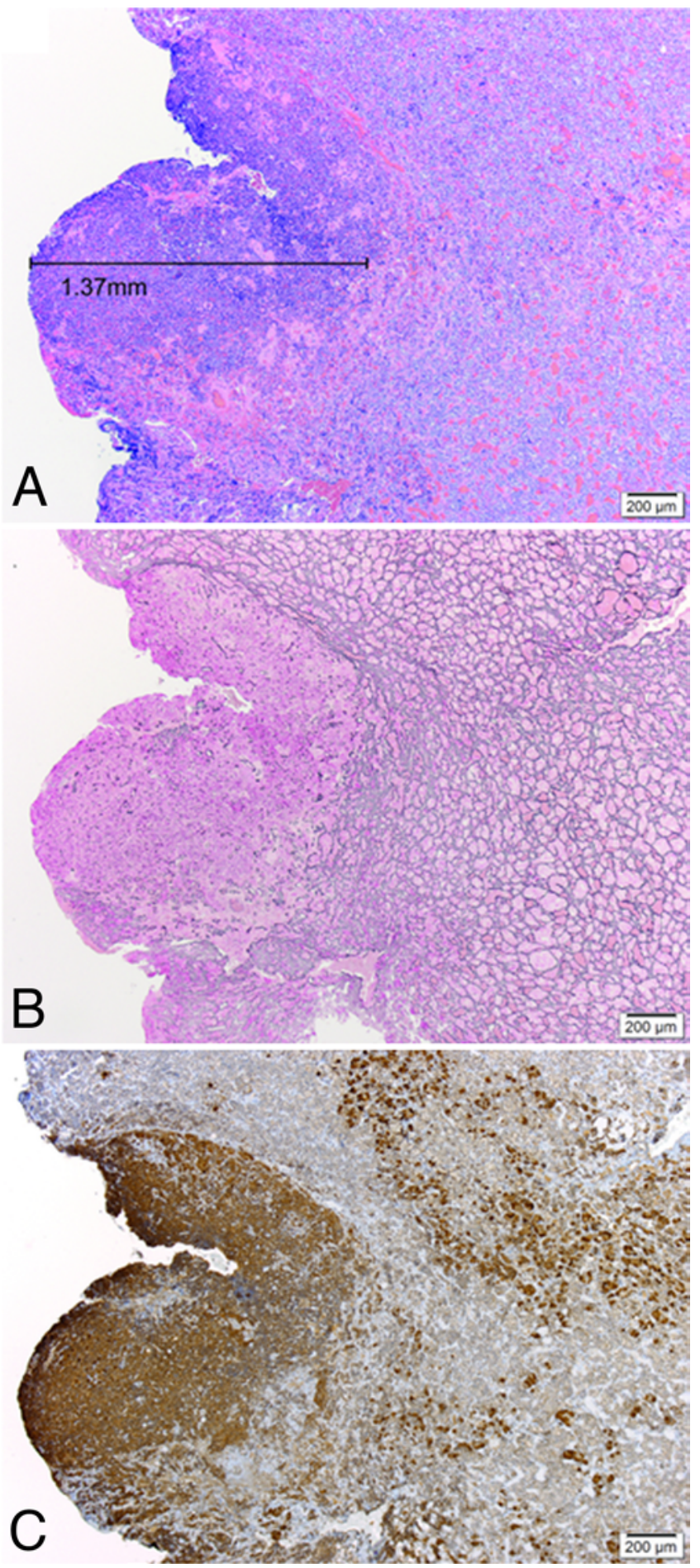

FIG. 2. Example of permanent histopathological section from a patient who was eventually found to have a small corticotroph adenoma in materials not sent for frozen sectioning. A and B: These sections illustrate the minute size of these lesions, namely $1.37 \mathrm{~mm}$ in the greatest dimension $(A, H \& E)$, with disruption of the acinar pattern proving the existence of adenoma, however small in size ( $B$, reticulin stain). Despite the small size of this example, it was actually the largest of the minute-sized pituitary adenomas identified in this study. C: ACTH immunohistochemistry. Original magnification $\times 20(\mathrm{~A}-\mathrm{C})$. had Crooke's cells recognized at the time of the initial examination. Of the remaining 4 cases, 2 showed occasional Crooke's cells on review, which were best identified on the multiple ACTH immunostains performed at the time of the initial diagnosis. One did not manifest Crooke's cells, even on review. Thus, for 2 of 13 cases, there was no morphological proof of hypercortisolism based on the presence of Crooke's cells (at least in the tissues sent to pathology for histological examination).

\section{Rate of Remission}

Overall, at last follow-up $18(81.8 \%)$ of the 22 patients had no evidence of hypercortisolism, and 4 patients (18.2\%) exhibited persistent hypercortisolism (Fig. 3). Of these latter 4 patients, 1 was suspected of harboring an ACTH-secreting adenoma in the cavernous sinus, 1 was subsequently diagnosed with an ACTH-secreting nonsmall cell lung carcinoma, 1 subsequently underwent resection of a lung lesion consistent with an ACTH- and CRH-secreting carcinoid tumor 17 years after TSS, and 1 still had an undiagnosed source for hypercortisolism.

\section{Follow-Up}

Patients were followed postoperatively by both the neurosurgery and the pituitary endocrinology services. By definition, initial remission was defined as a postoperative cortisol level $<5 \mu \mathrm{g} / \mathrm{dl}$. Below normal levels of morning cortisol have been shown to be predictive of long-term remission. ${ }^{24,32}$ Patients who met this criterion were started on an oral glucocorticoid postoperatively, with an aim to taper to physiological levels over several weeks. Recovery of the hypothalamic-pituitary-adrenocortical (HPA) axis was then determined periodically by intermittent basal morning cortisol testing. A corticotropin stimulation test was performed, as indicated, to determine HPA axis recovery prior to glucocorticoid discontinuation. Patients were then generally evaluated clinically and biochemically with 24-hour urinary-free cortisol levels on an annual basis for evidence of recurrent CD.

Mean follow-up was 98.9 months (median 77 months,

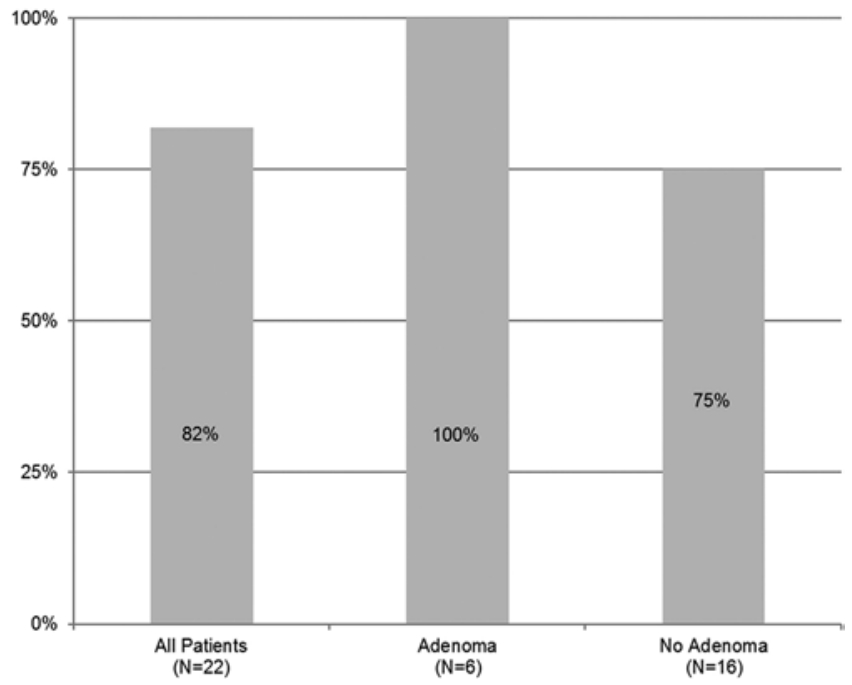

FIG. 3. Graph of remission status after two-thirds gland resection. 
range 14-315 months). Of the 6 patients with final pathology confirming an adenoma, all were in remission (100\%) at last follow-up (mean 114 months; Fig. 3). In the 3 patients with suspected ACTH-cell hyperplasia, 2 of the 3 remained in long-term remission at last follow-up (mean 143 months). Of the remaining 13 patients who had no adenoma or hyperplasia on final histopathology, 10 (76.9\%) were in remission at last follow-up (mean 81.7 months). Overall, in patients who did not have adenoma discovered, $12(75 \%)$ of 16 were in remission at last follow-up (mean 93.2 months).

\section{Complications}

Two patients required placement of a lumbar CSF drain immediately following surgery for a postoperative CSF leak, with no patient requiring reoperation. No patient suffered a postoperative neurological deficit attributable to surgery, bleeding complications, or long-term diabetes insipidus. All patients were evaluated between 3 and 12 months following surgery for the finding of a new pituitary endocrinopathy as a result of the two-thirds gland resection. Two patients $(9.1 \%)$ were found to have new deficits, requiring hormone replacement. Both of these patients required thyroid replacement, with 1 patient requiring additional testosterone replacement.

\section{Discussion}

Cushing's disease is most commonly caused by an ACTH-secreting microadenoma, and resection is the first- line treatment, resulting in high initial postoperative remission rates (around 70\%-90\%) at experienced centers. There is no consensus on the criteria for remission after resection of an $\mathrm{ACTH}$-producing tumor, but it is generally defined as a morning serum cortisol value $<5 \mu \mathrm{g} / \mathrm{dl}(<$ $138 \mathrm{nmol} / \mathrm{L}$ ) or a normalized 24-hour urinary-free cortisol level within 7 days of tumor resection. A risk factor for persistent hypercortisolism has been reported to include failed intraoperative tumor detection in an average of $21.8 \%$ of cases (range $1.4 \%-38 \%$ ), with an associated CD persistence/recurrence rate between $36 \%$ and $69 \%$. $^{16,18,19,23}$

In our review of the literature, the majority of studies (6/10), including contemporary series of single-surgeon experience at tertiary pituitary centers, support lower postoperative remission rates in patients with $C D$ without a histologically confirmed ACTH tumor compared with tumor detection (Table 2). For example, in an early report by Guilhaume and collegues, ${ }^{15}$ a high rate of failed ACTH tumor detection $(22 / 58,38 \%)$ was observed in their series of patients with $\mathrm{CD}$, and an immediately successful surgical outcome, defined as a normal 24-hour urinary-free cortisol, was observed in only $9(41 \%)$ of 22 in the group without an identified adenoma versus $32 / 36$ patients (89\%) with an identified ACTH adenoma. Limitations in this study include a failure to report the use of IPSS (the gold standard for establishing a pituitary etiology) and the use of nonstandardized testing for remission.

Sonino and colleagues ${ }^{28}$ reported on a series of 103 patients with CD in which $22(21 \%)$ had no tumor found on histopathology. The overall remission rate for the entire

\section{TABLE 2. Review of the literature}

\begin{tabular}{|c|c|c|c|c|c|c|c|c|c|}
\hline \multirow[b]{2}{*}{$\begin{array}{l}\text { Authors } \\
\text { \& Year }\end{array}$} & \multirow[b]{2}{*}{$\begin{array}{l}\text { Total } \\
\text { Cases }\end{array}$} & \multirow[b]{2}{*}{ EOR if No Tumor Found } & \multirow{2}{*}{$\begin{array}{c}\text { Absent } \\
\text { Tumor } \\
(\%)\end{array}$} & \multicolumn{2}{|c|}{ Initial Remission } & \multirow{2}{*}{$\begin{array}{l}\text { Relapse } \\
\text { Total } \\
(\%)\end{array}$} & \multirow[b]{2}{*}{ FU Period } & \multirow[b]{2}{*}{ Definition of Remission } & \multirow[b]{2}{*}{ IPSS } \\
\hline & & & & $\begin{array}{c}\text { Tumor } \\
(\%)\end{array}$ & $\begin{array}{c}\text { No Tumor } \\
(\%)\end{array}$ & & & & \\
\hline $\begin{array}{r}\text { Hammer et } \\
\text { al., } 2004\end{array}$ & 289 & $\begin{array}{l}\text { Partial }(n=3) \text {, hemi } \\
\qquad(n=22), \text { total }(n=23)\end{array}$ & 12.5 & 83.3 & 69.4 & 8.6 & $\begin{array}{l}\text { Median } \\
11.1 \mathrm{yrs}\end{array}$ & $\begin{array}{l}\text { Basal or low-dose DST cortisol }<5 \\
\quad \mu \mathrm{g} / \mathrm{dl}(<140 \mathrm{nmol} / \mathrm{L})\end{array}$ & Selective \\
\hline $\begin{array}{l}\text { Yap et al., } \\
2002\end{array}$ & 97 & Not reported & 29.3 & 66.6 & 63.6 & 11.5 & $\begin{array}{l}\text { Mean } 92 \\
\text { mos }\end{array}$ & Postop cortisol $<50 \mathrm{nmol} / \mathrm{L}$ & $\begin{array}{c}\text { Done in } \\
27 \%\end{array}$ \\
\hline $\begin{array}{r}\text { Sheehan et } \\
\text { al., } 2000\end{array}$ & 161 & Not reported & 18 & NA & 66 & 5 & $\begin{array}{l}\text { Mean } 38 \\
\text { mos }\end{array}$ & Normal or low 24-hr UFC & Selective \\
\hline $\begin{array}{r}\text { Comtois et } \\
\text { al., } 1993\end{array}$ & 22 & Central partial $(n=11)$ & 50 & 91 & 82 & 0 & $\begin{array}{l}\text { Mean } 1.3 \\
\text { yrs }\end{array}$ & $\begin{array}{l}\text { 1-wk postop plasma cortisol }<200 \\
\text { nmol/L at } 8 \text { AM }\end{array}$ & None \\
\hline $\begin{array}{l}\text { Mampalam et } \\
\text { al., } 1988\end{array}$ & 216 & $\begin{array}{l}\text { Total }(n=25), \text { partial } \\
\quad(n=7), \text { biopsy }(n=12)\end{array}$ & 21 & 81 & 69 & 4 & $\begin{array}{l}\text { Mean } 3.9 \\
\text { yrs }\end{array}$ & $\begin{array}{l}\text { Clinical resolution, normal plasma } \\
\text { cortisol \& ACTH, low-dose DST }\end{array}$ & $\ln 34 \%$ \\
\hline $\begin{array}{l}\text { Pouratian et } \\
\text { al., } 2007\end{array}$ & 490 & $\begin{array}{l}\text { Partial }(n=34), \text { hemi } \\
\quad(n=15), \text { total }(n=28)\end{array}$ & 23 & 88 & 50 & 21 & $\begin{array}{l}\text { Median } 30 \\
\text { mos }\end{array}$ & $\begin{array}{l}\text { Postop cortisol <2, clinical resolu- } \\
\text { tion }\end{array}$ & $\ln 58 \%$ \\
\hline $\begin{array}{l}\text { Invitti et al., } \\
1999\end{array}$ & 426 & Not reported & 16 & 75 & 36 & 17 & $\begin{array}{l}\text { Median } 27 \\
\text { mos }\end{array}$ & $\begin{array}{l}\text { Clinical resolution, low/normal } \\
\text { UFC, low/normal ACTH/cortisol }\end{array}$ & $\ln 22 \%$ \\
\hline $\begin{array}{l}\text { Bakiri et al., } \\
\quad 1996\end{array}$ & 50 & Hemi $(n=22)$ & 18 & 77 & 22 & 28 & $\begin{array}{l}\text { Median } 72 \\
\text { mos }\end{array}$ & $\begin{array}{l}\text { Clinical resolution, normal low- } \\
\text { dose DST, circadian cortisol }\end{array}$ & None \\
\hline $\begin{array}{l}\text { Sonino et al., } \\
1996\end{array}$ & 103 & Not reported & 21 & 77 & 23 & 23 & $\begin{array}{l}\text { Median } 6 \\
\text { yrs }\end{array}$ & $\begin{array}{l}\text { Clinical resolution, UFC }<248 \\
\text { nmol/day, } 5-15 \text { days postop }\end{array}$ & Selective \\
\hline $\begin{array}{l}\text { Guilhaume et } \\
\text { al., } 1988\end{array}$ & 58 & $\operatorname{Hemi}(n=6)$ & 38 & 89 & 41 & 29 & $\begin{array}{l}\text { Median } 2 \\
\text { yrs }\end{array}$ & $\begin{array}{l}\text { 3-6 mos postop, } 24-\mathrm{hr} \text { urine }<90 \\
\mu \mathrm{g}(248 \mathrm{nmol}) / \mathrm{day}, 8 \text { PM plasma } \\
\text { cortisol }<100 \mathrm{ng} / \mathrm{ml}\end{array}$ & None \\
\hline
\end{tabular}

FU = follow-up; hemi = hemi-hypophysectomy; NA = not applicable; UFC = urinary-free cortisol. 
series was $77 \%$. Of those patients in remission, adenoma was found in $93.7 \%$ of patients, compared with $29.2 \%$ of patients not in remission ( $\mathrm{p}<0.001)$, with a median followup of 6 years. The extent of surgical exploration was not detailed in the report, with failures presumably related, in part, to the extent of pituitary gland exploration and tissue resection. Invitti and colleagues ${ }^{18}$ reported remission rates of $75 \%$ versus $36 \%$ in their study of 426 patients with $\mathrm{CD}$, with and without distinct ACTH tumor detection on pathology, respectively. In addition, Hammer et al. ${ }^{16}$ found no focal tumor in $62(21 \%)$ of 289 cases in their surgical series of patients with CD who underwent varying extents of resection (EORs). Ultimately, $83 \%$ of patients with confirmed CD experienced remission, compared with $69 \%$ of patients with negative histopathology.

In the largest series, Pouratian and colleagues ${ }^{23}$ reported on 490 patients, in whom varying degrees of resection were performed. In this group, $29 \%$ had no clear tumor discovered during TSS. In those patients in whom no tumor was ever found on final histopathology, these authors reported a $50 \%$ initial remission rate over a mean 45-month follow-up period, which was significantly lower than the $88 \%$ initial remission rate in patients with histologically proven ACTH-staining adenomas. Even in their most aggressive resections (hemi- or total hypophysectomies), initial remission rates remained less than $60 \%$.

In contrast to the above studies, several studies reported no prognostic importance of failed ACTH tumor detection at the time of surgery. ${ }^{14,17,19,22,26,34}$ For example, Hardy ${ }^{17}$ observed failed tumor detection in $12(16 \%)$ of 75 of patients with presumed CD. In his surgical series, an $83 \%$ remission rate was reported in patients with $\mathrm{CD}$ in whom no adenoma was identified who underwent selective hypophysectomy, central mucoid wedge resection $(n=10)$, or total hypophysectomy $(\mathrm{n}=2)$. This was compared with an $88 \%$ remission rate in CD with a distinct adenoma. Our personal extensive experience with CD microadenomas is that, unlike Hardy's observation, tumors were more commonly in the lateral gland (unpublished data). In support of this finding, Invitti and colleagues ${ }^{18}$ reported imaging evidence showing an ACTH adenoma in the lateral aspect of the gland in $82 \%$ of cases. We do not recommend total hypophysectomy due to the risk of hypopituitarism, as has been previously reported. ${ }^{24}$

Standardization of perioperative care has been proposed to optimize the treatment of CD. ${ }^{4}$ At present there are no guidelines for neurosurgeons to follow when faced with the inability to identify a discrete adenoma intraoperatively. In this paper we report our surgical strategy that carries a high remission rate, low morbidity, and low complication rate. Our operative strategy entails a systematic surgical approach with concomitant neuropathology evaluation. Specifically, we recommend meticulous exploration of the pituitary gland surface, and if no tumor is identified intraoperatively or on histology, then a sequential internal gland exploration, followed by a two-thirds gland resection as indicated if no discrete tumor is identified. Total hypophysectomy, unlike other surgical series, was not performed in any of our cases.

Our data showed that in the setting of an appropriate CD workup and extensive surgical exploration, only 22
(13.6\%) of our 161 total patients with CD undergoing surgery had no recognized tumor at the time of the operation. This compares favorably with the negative exploration rate reported in the literature (Table 2) and is likely reflective of an extensive surgical exploration and careful tumor specimen evaluation. Similar to previous reports, we found no clear relationship between failed ACTH tumor detection and age, sex, preoperative MRI findings, IPSS results, or an abnormal intraoperative finding, although our sample size was too small to conduct meaningful statistical analyses of these factors.

Regarding surgical outcomes, among our 22 patients who underwent TSS, $27.3 \%$ demonstrated an adenoma on final pathology, with a $100 \%$ long-term remission rate. In the remaining group of patients with no adenoma found (16 of 22), a two-thirds gland resection can still be expected to give a reasonable long-term remission rate (12/16, 75.0\%). Overall, $81.8 \%$ of all patients who underwent a two-thirds gland resection were in remission at last follow-up. The overall remission rate in this less than favorable group of patients is comparable to overall remission rates reported in most surgical series of CD in which all patients are included. $3,6,8,10,18,21,25,27,29,30$

Possible explanations for the favorable remission rates, despite failed tumor detection, include the presence of a tiny corticotroph adenoma that was lost in suction or a small tumor that evaded histopathological identification. Three of our patients were suspected of having ACTH hyperplasia, two of whom were in remission following surgery. Whether this was true hyperplasia remains unclear, as true ACTH hyperplasia as a cause of CD is very uncommon.

The low number of immediate postoperative complications was consistent with results in the literature ${ }^{7,21}$ and our own overall surgical experience (unpublished data). Specifically, 2 patients required placement of a lumbar CSF drain for a surgery-related CSF leak immediately following surgery, but no patient required reoperation. In addition, no patient suffered significant operative complications. The incidence of a new pituitary endocrinopathy as a result of our patients undergoing a two-thirds gland resection was $9.1 \%$, between 3 and 12 months following surgery.

Regarding the subsequent finding of an ectopic ACTH tumor in 2 (9\%) of our 22 patients, IPSS was misleading. IPSS generally has a high sensitivity and specificity (> $95 \%$ ) for distinguishing a pituitary from an ectopic ACTH source..$^{20}$ Nevertheless, diagnostic errors and false-positive results can occur, most notably with insufficient hypercortisolism at the time of testing, or the rare ectopic $\mathrm{CRH} /$ ACTH tumors (as demonstrated in 1 of our cases). As such, it is important that neurosurgeons work closely with experienced pituitary endocrinologists to ensure proper evaluation of patients with CD.

Some strengths of this study include a single-surgeon experience using an as yet unreported and uncommonly consistent surgical technique, which results in a surgical uniformity in the cohort. Our low negative exploration rate supports a detailed CD workup in most cases. Potential weaknesses of this study include a relatively small sample size. The duration of follow-up ( $>8$ years) in the current 
study compares favorably to those in other studies. We conclude that the myriad benefits of cured CD with this surgical approach likely outweigh the risks of partial pituitary gland dysfunction, while we acknowledge that larger series are needed to confirm the benefit of our surgical approach, particularly regarding long-term remission rates.

\section{Conclusions}

The diagnosis and treatment of $\mathrm{CD}$ is one of the most challenging entities that pituitary neurosurgeons, endocrinologists, and pathologists face. The ability to make a correct diagnosis and deliver a high likelihood of remission after surgery relies heavily on the performance of a meticulous workup and rational surgical strategy. Currently, when the neurosurgeon is faced with the inability to identify a discrete adenoma intraoperatively, there is little uniformity in the literature as to how to proceed. We describe a systematic surgical exploration and resection strategy that we have found useful, resulting in a high overall remission rate, with an acceptably low rate of morbidity. We believe this approach will be useful to help guide surgeons in the operative treatment of this particularly difficult group of patients.

\section{Acknowledgments}

We would like to recognize the work of Carolina Arias-Astete in data acquisition. We also thank Dr. Zach Folzenlogen for his artistic rendering (Fig. 1).

\section{References}

1. Aranda G, Enseñat J, Mora M, Puig-Domingo M, Martínez de Osaba MJ, Casals G, et al: Long-term remission and recurrence rate in a cohort of Cushing's disease: the need for long-term follow-up. Pituitary 18:142-149, 2015

2. Arnaldi G, Angeli A, Atkinson AB, Bertagna X, Cavagnini F, Chrousos GP, et al: Diagnosis and complications of Cushing's syndrome: a consensus statement. J Clin Endocrinol Metab 88:5593-5602, 2003

3. Atkinson AB, Kennedy A, Wiggam MI, McCance DR, Sheridan B: Long-term remission rates after pituitary surgery for Cushing's disease: the need for long-term surveillance. Clin Endocrinol (Oxf) 63:549-559, 2005

4. Ayala A, Manzano AJ: Detection of recurrent Cushing's disease: proposal for standardized patient monitoring following transsphenoidal surgery. J Neurooncol 119:235-242, 2014

5. Bakiri F, Tatai S, Aouali R, Semrouni M, Derome P, Chitour F, et al: Treatment of Cushing's disease by transsphenoidal, pituitary microsurgery: prognosis factors and long-term follow-up. J Endocrinol Invest 19:572-580, 1996

6. Barbetta L, Dall'Asta C, Tomei G, Locatelli M, Giovanelli M, Ambrosi B: Assessment of cure and recurrence after pituitary surgery for Cushing's disease. Acta Neurochir (Wien) 143:477-482, 2001

7. Barker FG II, Klibanski A, Swearingen B: Transsphenoidal surgery for pituitary tumors in the United States, 1996-2000: mortality, morbidity, and the effects of hospital and surgeon volume. J Clin Endocrinol Metab 88:4709-4719, 2003

8. Bochicchio D, Losa M, Buchfelder M: Factors influencing the immediate and late outcome of Cushing's disease treated by transsphenoidal surgery: a retrospective study by the European Cushing's Disease Survey Group. J Clin Endocrinol Metab 80:3114-3120, 1995

9. Chandler WF, Barkan AL, Hollon T, Sakharova A, Sack J,
Brahma B, et al: Outcome of transsphenoidal surgery for Cushing disease: a single-center experience over 32 years. Neurosurgery 78:216-223, 2016

10. Chee GH, Mathias DB, James RA, Kendall-Taylor P: Transsphenoidal pituitary surgery in Cushing's disease: can we predict outcome? Clin Endocrinol (Oxf) 54:617-626, 2001

11. Ciric I, Zhao JC, Du H, Findling JW, Molitch ME, Weiss RE, et al: Transsphenoidal surgery for Cushing disease: experience with 136 patients. Neurosurgery 70:70-81, 2012

12. Clayton RN, Raskauskiene D, Reulen RC, Jones PW: Mortality and morbidity in Cushing's disease over 50 years in Stoke-on-Trent, UK: audit and meta-analysis of literature. J Clin Endocrinol Metab 96:632-642, 2011

13. Colao A, Faggiano A, Pivonello R, Pecori Giraldi F, Cavagnini F, Lombardi G: Inferior petrosal sinus sampling in the differential diagnosis of Cushing's syndrome: results of an Italian multicenter study. Eur J Endocrinol 144:499-507, 2001

14. Comtois R, Beauregard H, Hardy J, Robert F, Somma M: High prolactin levels in patients with Cushing's disease without pathological evidence of pituitary adenoma. Clin Endocrinol (Oxf) 38:601-607, 1993

15. Guilhaume B, Bertagna X, Thomsen M, Bricaire C, VilaPorcile E, Olivier L, et al: Transsphenoidal pituitary surgery for the treatment of Cushing's disease: results in 64 patients and long term follow-up studies. J Clin Endocrinol Metab 66:1056-1064, 1988

16. Hammer GD, Tyrrell JB, Lamborn KR, Applebury CB, Hannegan ET, Bell S, et al: Transsphenoidal microsurgery for Cushing's disease: initial outcome and long-term results. J Clin Endocrinol Metab 89:6348-6357, 2004

17. Hardy J: Presidential address: XVII Canadian Congress of Neurological Sciences. Cushing's disease: 50 years later. Can J Neurol Sci 9:375-380, 1982

18. Invitti C, Pecori Giraldi F, de Martin M, Cavagnini F: Diagnosis and management of Cushing's syndrome: results of an Italian multicentre study. J Clin Endocrinol Metab 84:440448, 1999

19. Mampalam TJ, Tyrrell JB, Wilson CB: Transsphenoidal microsurgery for Cushing disease. A report of 216 cases. Ann Intern Med 109:487-493, 1988

20. Oldfield EH, Doppman JL, Nieman LK, Chrousos GP, Miller DL, Katz DA, et al: Petrosal sinus sampling with and without corticotropin-releasing hormone for the differential diagnosis of Cushing's syndrome. N Engl J Med 325:897-905, 1991

21. Patil CG, Lad SP, Harsh GR, Laws ER Jr, Boakye M: National trends, complications, and outcomes following transsphenoidal surgery for Cushing's disease from 1993 to 2002. Neurosurg Focus 23(3):E7, 2007

22. Patil CG, Veeravagu A, Prevedello DM, Katznelson L, Vance ML, Laws ER Jr: Outcomes after repeat transsphenoidal surgery for recurrent Cushing's disease. Neurosurgery 63:266271,2008

23. Pouratian N, Prevedello DM, Jagannathan J, Lopes MB, Vance ML, Laws ER Jr: Outcomes and management of patients with Cushing's disease without pathological confirmation of tumor resection after transsphenoidal surgery. J Clin Endocrinol Metab 92:3383-3388, 2007

24. Rees DA, Hanna FWF, Davies JS, Mills RG, Vafidis J, Scanlon MF: Long-term follow-up results of transsphenoidal surgery for Cushing's disease in a single centre using strict criteria for remission. Clin Endocrinol (Oxf) 56:541-551, 2002

25. Semple PL, Laws ER Jr: Complications in a contemporary series of patients who underwent transsphenoidal surgery for Cushing's disease. J Neurosurg 91:175-179, 1999

26. Sheehan JM, Lopes MB, Sheehan JP, Ellegala D, Webb KM, Laws ER Jr: Results of transsphenoidal surgery for Cushing's disease in patients with no histologically confirmed tumor. Neurosurgery 47:33-39, 2000 
27. Shimon I, Ram Z, Cohen ZR, Hadani M: Transsphenoidal surgery for Cushing's disease: endocrinological follow-up monitoring of 82 patients. Neurosurgery 51:57-62, 2002

28. Sonino N, Zielezny M, Fava GA, Fallo F, Boscaro M: Risk factors and long-term outcome in pituitary-dependent Cushing's disease. J Clin Endocrinol Metab 81:2647-2652, 1996

29. Starke RM, Reames DL, Chen CJ, Laws ER, Jane JA Jr: Endoscopic transsphenoidal surgery for Cushing disease: techniques, outcomes, and predictors of remission. Neurosurgery 72:240-247, 2013

30. Swearingen B, Biller BM, Barker FG II, Katznelson L, Grinspoon S, Klibanski A, et al: Long-term mortality after transsphenoidal surgery for Cushing disease. Ann Intern Med 130:821-824, 1999

31. Tindall GT, Herring CJ, Clark RV, Adams DA, Watts NB: Cushing's disease: results of transsphenoidal microsurgery with emphasis on surgical failures. J Neurosurg 72:363-369, 1990

32. Trainer PJ, Lawrie HS, Verhelst J, Howlett TA, Lowe DG, Grossman AB, et al: Transsphenoidal resection in Cushing's disease: undetectable serum cortisol as the definition of successful treatment. Clin Endocrinol (Oxf) 38:73-78, 1993

33. Tritos NA, Biller BM, Swearingen B: Management of Cushing disease. Nat Rev Endocrinol 7:279-289, 2011

34. Yap LB, Turner HE, Adams CB, Wass JA: Undetectable postoperative cortisol does not always predict long-term remission in Cushing's disease: a single centre audit. Clin Endocrinol (Oxf) 56:25-31, 2002

\section{Disclosures}

The authors report no conflict of interest concerning the materials or methods used in this study or the findings specified in this paper.

\section{Author Contributions}

Conception and design: Lillehei, Carr, Kleinschmidt-DeMasters, Kerr. Acquisition of data: Lillehei, Carr, Kleinschmidt-DeMasters, Kerr, Wierman. Analysis and interpretation of data: all authors. Drafting the article: all authors. Critically revising the article: all authors. Reviewed submitted version of manuscript: Lillehei, Carr, Kleinschmidt-DeMasters, Kerr, Wierman. Approved the final version of the manuscript on behalf of all authors: Lillehei. Administrative/technical/material support: Lillehei, KleinschmidtDeMasters. Study supervision: Lillehei.

\section{Supplemental Information \\ Previous Presentations}

A portion of this data was presented previously as an oral presentation at the 28th Annual Neurosurgery in the Rockies Conference in Victoria, British Columbia, Canada, in June 2014.

\section{Correspondence}

Kevin O. Lillehei, University of Colorado, Neurosurgery, PO Box 6511, 12631 E 17th Ave., Box C-307, Aurora, CO 80045. email: kevin.lillehei@ucdenver.edu. 